\title{
Genetic diversity of Ralstonia solanacearum, A phytopathogenic bacterium infecting horticultural plants in Java, Indonesia
}

\author{
NIARSI MERRY HEMELDA ${ }^{1, \vartheta}$, RAMADHANI SAFITRI ${ }^{2, v \vee}$, SONY SUHANDONO ${ }^{1, v \vee \downarrow}$ \\ ${ }^{1}$ Graduate School of Biotechnology, School of Life Sciences and Technology, Institut Teknologi Bandung, Jl. Ganesa 10, Bandung 40132, Jawa Barat, \\ Indonesia. Tel./Fax. +62 22251 1575; +62 22250 0258/ +62 22253 4107, `email: merry.hemelda@sci.ui.ac.id.; ${ }^{\vee v v e m a i l: ~ s o n y @ ~ s i t h . i t b . a c . i d . ~}$ \\ ${ }^{2}$ Laboratory of Plant Pathology, Research and Development Division, East-West Seed Indonesia, Desa Benteng, Kecamatan Campaka, Purwakarta \\ 41181, Jawa Barat, Indonesia. Tel./Fax. +62 264 201871/ +62 264 201875, ^vemail: ramadhani@ panahmerah.id.
}

Manuscript received: 4 January 2019. Revision accepted: 14 January 2019.

\begin{abstract}
Hemelda NM, Safitri R, Suhandono S. 2019. Genetic diversity of Ralstonia solanacearum, A phytopathogenic bacterium infecting horticultural plants in Java, Indonesia. Biodiversitas 20: 364-372. Ralstonia solanacearum is a phytopathogenic bacterium causing bacterial wilt disease which has been reported to infect many important plants in Indonesia. However, less study has been done on its genetic diversity in Indonesia. This study aimed to investigate the genetic diversity of $R$. solanacearum virulent strains isolated from Java Island. BOX-PCR fingerprint was carried out to investigate the genetic pattern of $R$. solanacearum isolates, while phylogenetic analysis of $m u t S$ gene was performed to determine the genetic diversity of $R$. solanacearum isolates. A total of 21 isolates was obtained from four crop species: twenty isolates identified as phylotype I while one isolate identified as phylotype II. Based on BOX-PCR, most of the isolates clustered according to their original provinces, indicating site-dependent distribution pattern. However, BOX-PCR also detected site-contaminations indicated by the similar genetic patterns found in two provinces. Phylogenetic analysis of mutS gene discovered that most of the phylotype I isolate showed $100 \%$ similarity to each other, while phylotype II isolate belonged to phylotype IIB and showed 100\% similarity to IPO1609 strain. Pathogenicity and biovar test were confirmed that the phylotype IIB isolate belonged to the R3bv2 strain which was adapted in low temperature. This study provided the first description about genetic diversity patterns of $R$. solanacearum strains in Java Island and revealed new challenges related to how to prevent contamination of $R$. solanacearum from one province to another, as well as the phylotype IIB strain infection in a highland area in Indonesia.
\end{abstract}

Keywords: BOX-PCR, genetic diversity, mutS gene, Ralstonia solanacearum.

\section{INTRODUCTION}

Ralstonia solanacearum (Smith) Yabuuchi et al. is a phytopathogenic bacterium causing bacterial wilt disease (Yabuuchi et al. 1995). It is worldwide distributed with broad-ranged of host species. Over 200 plant species in 50 botanical families have been reported so far as its hosts (Schell 2000). Some of them are economically important crops, such as tomato, potato, tobacco, banana, and peanut (Hayward 1991; Elphinstone 2005).

Ralstonia solanacearum is a heterogenic species with only $60 \%$ homology of DNA among the strains. The low homology of DNA indicates that $R$. solanacearum is a species complex with high genetic diversity at infraspecific level (Fegan and Prior 2005). Traditionally, $R$. solanacearum has been classified into five races based on its host range, and into six biovars based on its carbohydrate oxidation ability (Hayward 1964; Hayward, 1991). However, those phenotypic-based classifications are not considered as reliable classifications. Fegan and Prior (2005) then proposed a new "phylotype" classification scheme on the basis of phylogenetic analysis of the internal transcribed spacer (ITS) region, egl gene, and $h r p B$ gene which classified $R$. solanacearum into four phylotypes: phylotype I "Asiaticum", phylotype II "Americanum", phylotype III "Africa", and phylotype IV "Indonesia". Prior and Fegan (2005) reinforced the phylotyping scheme by analyzing the phylogenetic tree based on the mutS partial gene sequence which encodes for a DNA mismatch repair protein called mutS protein.

Besides phylogenetic analysis, another method which has been used for studying genetic diversity is repetitive PCR (rep-PCR). The rep-PCR is a PCR-based genomic fingerprinting targeting repetitive elements in bacterial genomes as the amplification targets (Olive and Bean 1999). However, rep-PCR assesses the genetic diversity using a different approach from the phylogenetic analysis. Phylogenetic analysis uses multiple sequence alignment to construct the phylogenetic tree based on the change of nucleotides of the sequences caused by insertion-deletion, transversion, and transition (Phillips et al. 2000), while repPCR, as other PCR-based typing methods, uses the pattern of DNA bands produced by PCR amplification to analyze the similarity of clonally related individuals (Olive and Bean 1999).

There are three bacterial repetitive elements targeted for rep-PCR: REP and ERIC elements (Lupski and Weinstock 1992), and BOX elements (Koeuth et al. 1995). Among those three repetitive elements, rep-PCR using BOX elements (BOX-PCR) performs the best discriminatory power in the term of the number of DNA bands produced (Arshiya et al. 2014) and the gene diversity index (Muiru et al. 2010). In general, rep-PCR had considerably better discriminatory power than AP-PCR and amplified rDNA 
restriction analysis (Vila et al. 1996) with the lower cost compared to other DNA-based typing methods, such as PFGE, RFLP, CFLP, and AFLP (Olive and Bean 1999).

In Indonesia, less work has been done on genetic diversity of $R$. solanacearum strains. Most of $R$.solanacearum studies have been focusing on bacterial wilt disease control, either by application of antagonistic bacteria (Nasrun and Nurmansyah 2016; Saputra et al. 2015; Yanti et al. 2017) or developing new resistant varieties of plants (Adriani et al. 2012; Hartati et al. 2015). Most of them involved only one $R$. solanacearum strain in each study. However, the pathogenicity of $R$. solanacearum strains is varied from one strain to another (Nasrun et al. 2007). For this reason, establishing bacterial wilt control management without considering variations in pathogenicity of $R$. solanacearum may cause ineffectiveness of bacterial wilt disease control. Genetic background is one of many factors contributing variations in $R$. solanacearum pathogenicity and virulence (Wicker et al. 2007; Suga et al. 2013).

Although $R$. solanacearum has been an important pathogen in agriculture in Java Island, Indonesia, there has been no detailed reports available on the genetic diversity of $R$. solanacearum in Indonesia, especially in Java Island. Therefore, in this study, we explored the genetic patterns of $R$. solanacearum from Java Island employing BOX-PCR fingerprint and investigated the relationship between the $R$. solanacearum from Java Island and the other reference strains of $R$. solanacearum through the phylogenetic analysis of the mutS gene. This study is expected to provide baseline information about the genetic diversity of $R$. solanacearum in Indonesia which will be useful for breeders to develop resistant varieties of host plants or other strategies to control $R$. solanacearum infection.

\section{MATERIALS AND METHODS}

\section{Bacterial isolation}

Plants with bacterial wilt disease symptoms were collected from three provinces in Java Island: West Java, Central Java, and East Java, from January until August 2015 by the staffs of Plant Pathology, East-West Seed Indonesia. Isolation of $R$. solanacearum from infected plants using triphenyl tetrazolium chloride (TTC) agar medium was carried out as described by Sagar et al. (2014). Single slimy, milky colonies with pink center were transferred to nutrient agar medium for multiplication.

\section{DNA extraction}

Bacterial DNA was extracted using DNEasy Blood and Tissue (Qiagen). DNA concentration then was measured using MultiskanTM GO Microplate Spectrophotometer (Thermo Scientific) and standardized into 50-60 ng $\mu \mathrm{L}^{-1}$. This DNA extract was used as DNA template for phylotype identification, BOX-PCR, and mutS gene sequencing.

\section{Phylotype identification}

Phylotype-specific multiplex PCR (Pmx-PCR) includes seven primers targeting the ITS region: primers $759 \mathrm{~F} / 760 \mathrm{R}$
(Opina et al. 1997) as an internal marker, and four phylotype-specific forward primers, with a unique and conserved reverse primer (Fegan and Prior 2005). This Pmx-PCR produces two DNA bands for each sample: the internal marker band and a phylotype-specific DNA band. PCR reaction mixtures of $10 \mu \mathrm{L}$ volume contained $1 \mathrm{x}$ KAPA2G Fast ReadyMix (KAPA Biosystems), $1 \mu \mathrm{L}$ primer mix $(2 \mu \mathrm{M}$ of each primer Nmult21:F, Nmult21:2F, Nmult23:AF, Nmult22:InF; and Nmult22:RR, and $1 \mu \mathrm{M}$ each primer $759 \mathrm{~F} / 760 \mathrm{R}$ ), and $0.5 \mu \mathrm{L}$ DNA template. PCR reaction was performed according to the protocol: (i) initial denaturation at $96^{\circ} \mathrm{C}$ for $5 \mathrm{~min}$, (ii) 30 cycles of denaturation at $94^{\circ} \mathrm{C}$ for $15 \mathrm{sec}$, annealing at $59.4^{\circ} \mathrm{C}$ for 30 $\mathrm{sec}$, and elongation at $72^{\circ} \mathrm{C}$ for $30 \mathrm{sec}$, (iii) final elongation at $72^{\circ} \mathrm{C}$ for $10 \mathrm{~min}$.

\section{Hypersensitive response, symptoms cross-tests, and biovar test}

All of the $R$. solanacearum isolates were tested for their virulence using leaf-injection hypersensitive response test on tobacco leaf according to Lozano and Sequeira (1969). Bacterial suspension for hypersensitive response test was adjusted to $10^{8} \mathrm{cfu} \mathrm{mL}^{-1}$ by spectrophotometry $\left(\mathrm{OD}_{600}=\right.$ 0.8 ) before the injection. Symptoms cross-tests were carried out only for isolates from uncommon hosts (IDPW4128) and belonged to uncommon phylotype (IDGR3114) to make sure that they were able to infect the original host species and develop the same symptoms of bacterial wilt. For IDPW4128 isolate, the cross-test was carried out in two plant species: (a) common bean, the line from which it was isolated, and (b) long bean (Parade Tavi), while for IDGR3114 isolate, the cross-test was carried out in three susceptible lines of plant species: (a) tomato, from which it was isolated, (b) eggplant, and (c) pepper. For comparison to IDGR3114 isolate, we also performed the test for three other isolates from tomato as well from each province: West Java (IDLB3211), Central Java (IDKL3224), and East Java (IDBL3127). All of the seeds used for cross-tests were provided by East West Seed Indonesia.

Bacterial strains were transferred from TTC medium to $\mathrm{NA}$ medium for $48 \mathrm{~h}$ at $28^{\circ} \mathrm{C}$. The pure bacterial colonies were suspended into sterile Milli-Q water and adjusted to $10^{8} \mathrm{cfu} \mathrm{mL}^{-1}$. A total of 15 seedlings which were a four-leaf stage of each host species were selected for the tests. Inoculation was made by creating an artificial wound on the roots using a sterile blade then injecting $1 \mathrm{~mL}$ of bacterial suspension into the wounded root areas. The seedling condition was recorded at 14 days after inoculation by observing the symptoms which were developed and counting the presentation of wilted and died seedlings. All cross-tests were carried out in the screen houses of the Division of Research and Development, East West Seed Indonesia in Purwakarta.

Biovar test was only carried out on the IDGR3114 isolate. The isolate was cultured on TTC medium at $28^{\circ} \mathrm{C}$ for 48 hours to obtain one single colony. The single colony then was cultured on NA medium multiplication at $28^{\circ} \mathrm{C}$ for 48 hours. One loopful of bacterial colonies was immersed into sterile Milli-Q water and adjusted to $10^{8} \mathrm{cfu}$ 
$\mathrm{mL}^{-1}$ by spectrophotometry $\left(\mathrm{OD}_{600}=0.8\right)$ before the biovar test. Biovar test was performed according to Hayward (1964). The carbohydrate used in this test included glucose, lactose, maltose, cellobiose, trehalose, mannitol, sorbitol, and dulcitol. The change of the medium color into yellow indicated positive result was observed every three days until three weeks. The test was repeated three times.

\section{BOX-PCR analysis}

BOX-PCR was carried out in $25 \mu \mathrm{L}$ volume containing 1x KAPA2G Fast ReadyMix (KAPA Biosystems), $1 \mu \mathrm{M}$ primer BOX A1R (Koeuth et al. 1995), and $1 \mu \mathrm{L}$ DNA template, according to the protocol Xue et al. (2011). The DNA band patterns of BOX-PCR were analyzed and presented by a dendrogram which was generated by the unweighted pair group method with arithmetic averages (UPGMA) algorithm with Pearson's correlation coefficient as the coefficient of similarity using GelJ 1.3 (Heras et al. 2015).

\section{PCR amplification and DNA sequencing of the mutS gene}

The primer pair of mutS-RsF.1570 and mutS-RsR.1926 was used to amplify a 758-bp fragment of the terminal portion of the mutS gene (Prior and Fegan 2005). PCR reaction mixture $(20 \mu \mathrm{L})$ contained 1x KAPA2G Buffer A, $0.2 \mathrm{mM}$ dNTP mix, $0.5 \mu \mathrm{M}$ each primer mutS-RsF.1570 and mutS-RsR.1926, 0.5 U KAPA2G Robust HotStart DNA Polymerase (KAPA Biosystem), and $1 \mu \mathrm{L}$ DNA template. PCR reaction was performed according to the protocol: (i) initial denaturation at $95^{\circ} \mathrm{C}$ for $5 \mathrm{~min}$, (ii) 30 cycles of denaturation at $95^{\circ} \mathrm{C}$ for $30 \mathrm{sec}$, annealing at $61.1^{\circ} \mathrm{C}$ for $30 \mathrm{sec}$, and elongation at $72^{\circ} \mathrm{C}$ for $1 \mathrm{~min}$, (iii) final elongation at $72^{\circ} \mathrm{C}$ for $8 \mathrm{~min}$. PCR products were sent to Integrated DNA Technologies 1st Base, Singapore, for sequencing with pre-treatment of gel purification.

\section{Sequence analysis}

Multiple sequence alignment was performed using ClustalX2 (Larkin et al. 2007). The mutS gene sequences of $R$. solanacearum isolates used in this study (Table 1) and reference strains from GenBank (Table 2) were analyzed using MEGA 7.0 (Kumar et al. 2016). A phylogenetic tree was generated using a neighbor-joining algorithm and Jukes and Cantor as substitution model with 5000 times of bootstrap replication.

\section{RESULTS AND DISCUSSION}

\section{Bacterial isolation and phylotype identification}

A total of 21 isolates were isolated from four crop species (tomato, pepper, eggplant, and common bean) in West Java, Central Java, and East Java. Based on the result of Pmx-PCR, 20 of 21 isolates produced a 280-bp amplicon of an internal marker and a 144-bp amplicon specific to phylotype I, while one isolate (IDGR3114) produced a 280-bp amplicon of an internal marker and a 372-bp amplicon specific to phylotype II (Table 1). Based on the hypersensitive response test, all leaf tissues infiltrated by each of the isolates became necrotic before 24 hours. Necrosis in the infiltrated area occurs because of plant hypersensitive reaction to pathogens. Hypersensitive response is a programmed cell death in the area of pathogen invasion to prevent the pathogen from spreading to adjacent healthy tissue (Coll et al. 2011). As all isolates were able to trigger a hypersensitive response of tobacco leaves, all isolates were identified as virulent strains (Lozano and Sequeira 1969).

Table 1. List of $R$. solanacearum isolates obtained in this study

\begin{tabular}{|c|c|c|c|c|c|c|c|c|}
\hline \multirow{2}{*}{ Isolate } & \multirow{2}{*}{ Host } & \multirow{2}{*}{ City/District } & \multirow{2}{*}{ Province } & \multirow{2}{*}{$\begin{array}{l}\text { Hypersensitive } \\
\text { Response Test }\end{array}$} & \multicolumn{2}{|c|}{ Phylotype } & \multicolumn{2}{|c|}{ BOX-PCR } \\
\hline & & & & & PCR & mutS & Group & Cluster \\
\hline IDMG2120 & Eggplant & Magelang & Central Java & + & I & I & $\mathrm{A}$ & 1 \\
\hline IDGR3114 & Tomato & Garut & West Java & + & II & IIB & A & 2 \\
\hline IDKL3123 & Tomato & Klaten & Central Java & + & I & N/A & $\mathrm{A}$ & 3 \\
\hline IDKL1122 & Pepper & Klaten & Central Java & + & I & $\mathrm{I}$ & $\mathrm{A}$ & 3 \\
\hline IDMG2221 & Eggplant & Magelang & Central Java & + & I & N/A & A & 3 \\
\hline IDKD1126 & Pepper & Kediri & East Java & + & I & I & A & 3 \\
\hline IDKL3224 & Tomato & Klaten & Central Java & + & I & N/A & A & 3 \\
\hline IDBY2118 & Eggplant & Boyolali & Central Java & + & I & I & A & 3 \\
\hline IDLB3110 & Tomato & West Bandung & West Java & + & I & I & $\mathrm{B}$ & 4 \\
\hline IDLB3312 & Tomato & West Bandung & West Java & + & I & N/A & $\mathrm{B}$ & 5 \\
\hline IDLB3211 & Tomato & West Bandung & West Java & + & I & I & $\mathrm{B}$ & 5 \\
\hline IDPW3109 & Tomato & Purwakarta & West Java & + & I & N/A & B & 5 \\
\hline IDPW2507 & Eggplant & Purwakarta & West Java & + & I & $\mathrm{N} / \mathrm{A}$ & B & 5 \\
\hline IDPW2305 & Eggplant & Purwakarta & West Java & + & I & N/A & $\mathrm{B}$ & 5 \\
\hline IDSB2217 & Eggplant & Subang & West Java & + & I & N/A & B & 6 \\
\hline IDBL3127 • & Tomato & Blitar & East Java & + & I & $\mathrm{I}$ & $\mathrm{B}$ & 6 \\
\hline IDBR2118 & Eggplant & Brebes & Central Java & + & I & I & $\mathrm{B}$ & 6 \\
\hline IDPW4128 & Common bean & Purwakarta & West Java & + & I & N/A & $\mathrm{B}$ & 6 \\
\hline IDGR2115 & Eggplant & Garut & West Java & + & I & I & B & 6 \\
\hline IDPW2608 & Eggplant & Purwakarta & West Java & + & I & N/A & B & 6 \\
\hline IDPW1202 & Pepper & Purwakarta & West Java & + & $\mathrm{I}$ & I & $\mathrm{B}$ & 6 \\
\hline
\end{tabular}

Note: The representative isolates used for phylogenetic analysis of mutS gene were marked by symbol 
Cross-tests of DPW4128 isolate

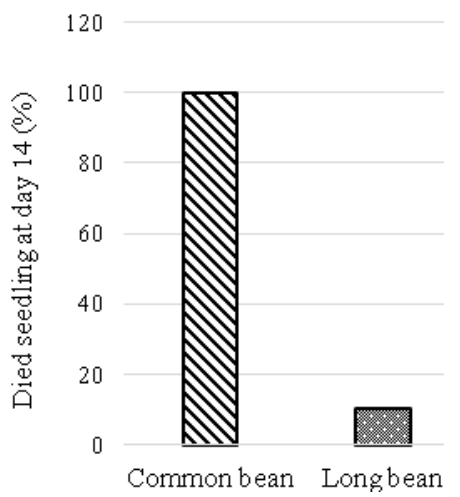

A
Cross-tests of four $R$. solanacearum strains isolated from tomato

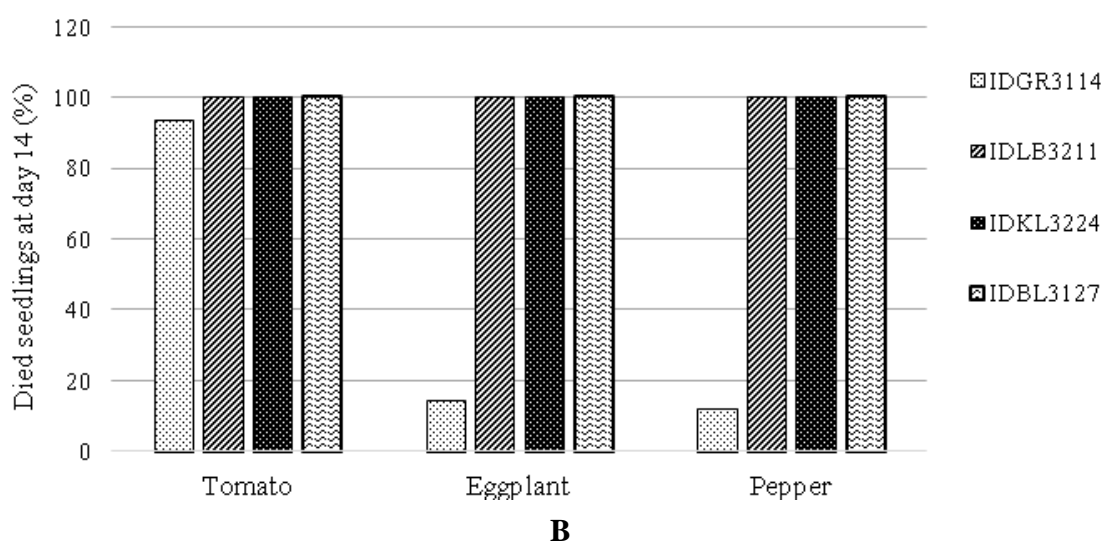

Figure 1. Cross-test of $R$. solanacearum isolates. A. The IDPW4128 isolate on common bean and long bean; B. The IDGR3114 and another phylotype I isolate on tomato, eggplant, and pepper

This study discovered that most of $R$. solanacearum strains infecting four crop plants in three provinces in Java Island belonged to phylotype I. It supports the previous study of Fegan and Prior (2005) that phylotype I is primarily distributed in Asia. From the four crop species, $R$. solanacearum infection rarely occurs in common bean. However, we obtained the IDPW4128 isolate (phylotype I) from the common bean in Purwakarta. The cross-test of IDPW4128 isolate in common bean showed that the isolate developed the bacterial wilt symptoms in common bean and long bean. However, it was less pathogenic to a long bean ( $10 \%$ of seedlings wilted then died) than common bean ( $100 \%$ of seedlings wilted then died) (Figure 1A).

Besides phylotype I, we also discovered a phylotype II strain (IDGR3114) infecting a tomato plant in West Java. Even though phylotype II strains are primarily distributed in America (Fegan and Prior 2005), they are also reported to be found in several countries in Asia, such as the Philippines (Prior and Fegan 2005), China (Xu et al. 2009), and India (Sagar et al. 2014). In Indonesia, along with this study, there are three phylotypes II strains which have been isolated so far. They were recorded infecting groundnut in Malang, East Java in 1991 (CIP418 strain) (Wicker et al. 2012), tomato in Wonosobo, Central Java (Salamah and Arwiyanto, 2015), and tomato in Garut, West Java (this study). Although there was no information about the detailed area about where CIP418 strains were isolated from, the other two strains were isolated from a highland area in Wonosobo (Salamah and Arwiyanto 2015) and Garut (this study). These strains are adaptive to lower temperature in highland areas.

The cross-test of the IDGR3114 (phylotype II) and the three phylotypes I isolate from tomato (IDLB3211, IDKL3224, and IDBL3127 showed that all isolates were able to develop bacterial wilt symptoms in tomato, pepper, and eggplant. However, the IDGR3114 isolate presented the highest pathogenicity to tomato, but very low pathogenicity to eggplant and pepper. On the other hand, the other three phylotypes I isolate showed high pathogenicity to all tested plant (Figure 1B). Based on this pathogenic characteristic, we identified the IDGR3114 phylotype II as the race 3 strain, which is highly pathogenic to potato and tomato but less pathogenic to other members of Solanaceae (Denny, 2006; Hayward 1991).

In general, race three strains are equivalent to biovar two strains (Hayward, 1991). To test whether the IDGR3114 isolate was a biovar 2 strains, we performed biovar test to the isolate. The biovar test presented that the isolate was able to oxidize only glucose, lactose, maltose, and cellobiose, but not trehalose, mannitol, sorbitol, and dulcitol (Figure 2). Based on this result, the isolate belonged to biovar 2 (Hayward, 1964). Therefore, the IDGR3114 was identified as $R$. solanacearum race 3 biovar 2 (R3bv2).

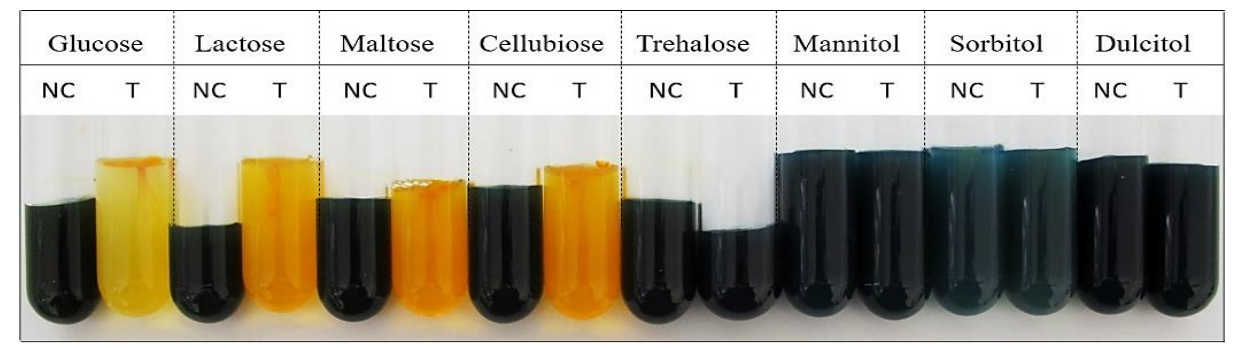

Figure 2. Biovar test on the IDGR3114 isolate. Yellow color indicated a positive result, (NC) negative control without bacterial injection, $(\mathrm{T})$ treatment with bacterial injection. 
Table 2. List of $m u t S$ gene sequence references used for phylogenetic analysis

\begin{tabular}{|c|c|c|c|c|c|}
\hline Strain & Host & Location & Phylotype & Reference & Accession No. \\
\hline \multicolumn{6}{|c|}{ Ralstonia solanacearum } \\
\hline GMI1000 & Tomato & French Guiana & I & \multirow[t]{2}{*}{ Wicker et al. 2007} & AY756804 \\
\hline NCPPB3190 & Tomato & Malaysia & I & & AY756738 \\
\hline TW56 & Tomato & Korea & I & \multirow[t]{3}{*}{ Jeong et al. 2007} & EF523217 \\
\hline SL341 & Tomato & Korea & I & & EF523213 \\
\hline N6211 & Pepper & Japan & I & & EF523220 \\
\hline CFBP3059 & Eggplant & Burkina Faso & III & \multirow[t]{11}{*}{ Wicker et al. 2007} & AY756766 \\
\hline CFBP734 & Potato & Madagascar & III & & AY756746 \\
\hline PSI07 & Tomato & Indonesia & IV & & AY756752 \\
\hline SL2029 & Potato & Korea & IV & & EF523214 \\
\hline CFBP2957 & Tomato & Martinique & IIA & & EF371845 \\
\hline CFBP2972 & Potato & Martinique & IIA & & AY756807 \\
\hline K60 & Tomato & America & IIA & & AY756799 \\
\hline CFBP6786 & Tomato & Martinique & IIB & & EF371858 \\
\hline CFBP6780 & Tomato & Martinique & IIB & & EF371864 \\
\hline MOLK2 & Musa sp. & Philippines & IIB & & EF371848 \\
\hline IPO1609 & Potato & The Netherlands & IIB & & EF371849 \\
\hline CIP418 & Groundnut & Indonesia & IIB & $\begin{array}{l}\text { Momol TM and Jones JB } \\
\text { (unpublished) }\end{array}$ & AY756809 \\
\hline \multicolumn{6}{|c|}{ Ralstonia mannitolilytica (outgroup) } \\
\hline CFBP6737 & & & & Holterman et al. (unpublished) & KC188199 \\
\hline
\end{tabular}

\section{BOX-PCR showed a site-dependent distribution}

BOX-PCR produced DNA bands ranged from $500 \mathrm{bp}$ to 4000 bp. Dendrogram of BOX-PCR showed that all isolates were divided into two groups based on $<80 \%$ similarity, and six clusters based on $92 \%$ similarity (Figure $3)$. Isolates from West Java were the most diverse based on their DNA band patterns as they showed four types of band pattern grouped into four clusters: cluster $2,4,5$, and 6 . It might be caused by the high number of samples obtained from West Java. IDGR3114 (cluster 2) was separated from most West Java isolates as it was the, but still, in the same group B. Isolates from Central Java showed less diverse compared to isolates from West Java. They showed three types of band pattern grouped into three clusters: cluster 1, 3 , and 5. However, isolates from East Java were the least diverse as they showed two types of band pattern, each type was represented by only one isolate. It might be caused by a low number of samples obtained from East Java as we started collecting samples from East Java areas in the dry season when $R$. solanacearum infection was lower than in the wet season.

Dendrogram obtained from BOX-PCR indicated distribution based on original provinces. Isolates from Central Java were mostly in group A, except IDBR2118 (cluster 5) isolated from eggplant in Brebes District. DNA band pattern of IDBR2118 was more similar to DNA band pattern of West Java isolates than of Central Java isolates. Since Brebes District is located on the border between West Java and Central Java, there is a possibility of $R$. solanacearum dispersal from West Java. Isolates from West Java were mostly in group B, except IDGR3114 (phylotype II R3bv2), while isolates from East Java were distributed in both groups.

The BOX patterns of isolates from the same plant species (eggplant, tomato, and pepper) were reanalyzed separately to check for their geographic distribution patterns. The isolate from common bean was excluded since it was only represented by one isolate. In tomato and eggplant, the isolates were clustered into two groups, the Central Java group, and West Java group. They were clustered based on their original provinces, except some isolates (Figure 4A-B). In pepper, isolate from East Java and Central Java presented higher similarity compared to the West Java isolate (Figure 4C).

This result supported a previous study of Xue et al. (2011) that BOX-PCR recognized some DNA band clusters which were specific to some areas. As soil bacteria have little capacity to cross significant geographic barriers, they will only disperse over very short distances, creating populations with similar individuals (Martiny et al. 2006). However, in this study, some other isolates did not show site-dependent distribution. As the site of origin is not the only factors affecting the genetic diversity of $R$. solanacearum, the genetic diversity may also be affected by what biovar it belongs to (Lemessa et al. 2010) and its host plant species (Xue et al. 2011).

Site-dependent distribution patterns revealed by BOXPCR fingerprint can also be used for strain-tracking 
purposes and detection of the origin of contamination (Ishii and Sadowsky 2009; Carlos et al. 2012). In this study, from two isolates from East Java, one isolate (IDKD1126) presented similar DNA pattern to Central Java isolates, while the other one (IDBL3127) presented similar DNA pattern to West Java isolates. It indicated a possibility that there were contaminations of strains from Central Java and West Java to East Java. Contaminations may occur accidentally by transfer of infected vegetative materials (Hayward 1991) or generative materials from one province to another. Although infection of $R$. solanacearum in generative materials is extremely rare, Perez et al. (2008) reported the rare occurrence of tomato fruit infection from $R$. solanacearum infected plant in Guatemala.

\section{Phylogenetic analysis of mutS gene}

For phylogenetic analysis, 11 isolates were chosen as the representative isolates based on BOX-PCR analysis. Each of BOX-PCR clusters was represented by at least one isolate. The phylogenetic tree showed that the four phylotypes were distinguished with high bootstrap values. Phylotype I was closer to phylotype III than phylotype IV. However, phylotype II was separated from the other phylotypes (Figure 5). Similar tree structure constructed by nine loci-concatenated sequence sets was presented as well by (Wicker et al. 2012) that phylotype II was the most differ while phylotype I and III were the two closest phylotypes.

Based on the mutS gene sequence, phylotype I isolates were phylogenetically undistinguishable from the GMI1000 type strain, except for the IDLB3110 isolate from West Java which varied only one nucleotide position. In BOX-PCR dendrogram, this isolate also showed different DNA band pattern to the other West Java isolates in group B. Even though phylotype I isolate in this study showed high genetic diversity according to BOX-PCR analysis, and their mutS gene sequences showed low genetic diversity. As BOX-PCR fingerprint assesses the genome structure of an organism, it is susceptible to genome changes caused by insertions, recombination between repeated sequences, and horizontal gene transfer (Ishii and Sadowsky 2009). For this reason, BOX-PCR fingerprint can perform high discriminative power in identifying bacterial clones (Norman et al. 2009; Proudy et al. 2007). However, the phylogenetic analysis provides a more reliable approach in identifying at a higher level such as sequevar or phylotype level (Norman et al. 2009).

The phylotype I isolate were phylogenetically similar based on mutS gene sequence even though they were obtained from various host plants: tomato, pepper, eggplant, and the uncommon host plants-common bean, therefore they were forming a clade together (Figure 5). Phylotype I is known as the phylotype with the highest number of host plants (Fegan and Prior 2005). The ability to infect many host species is possibly related to recombination process in which phylotype $I$, in its evolutionary process, received gene transfers from phylotype IIA, phylotype IIB, and phylotype IV (Wicker et al. 2012).

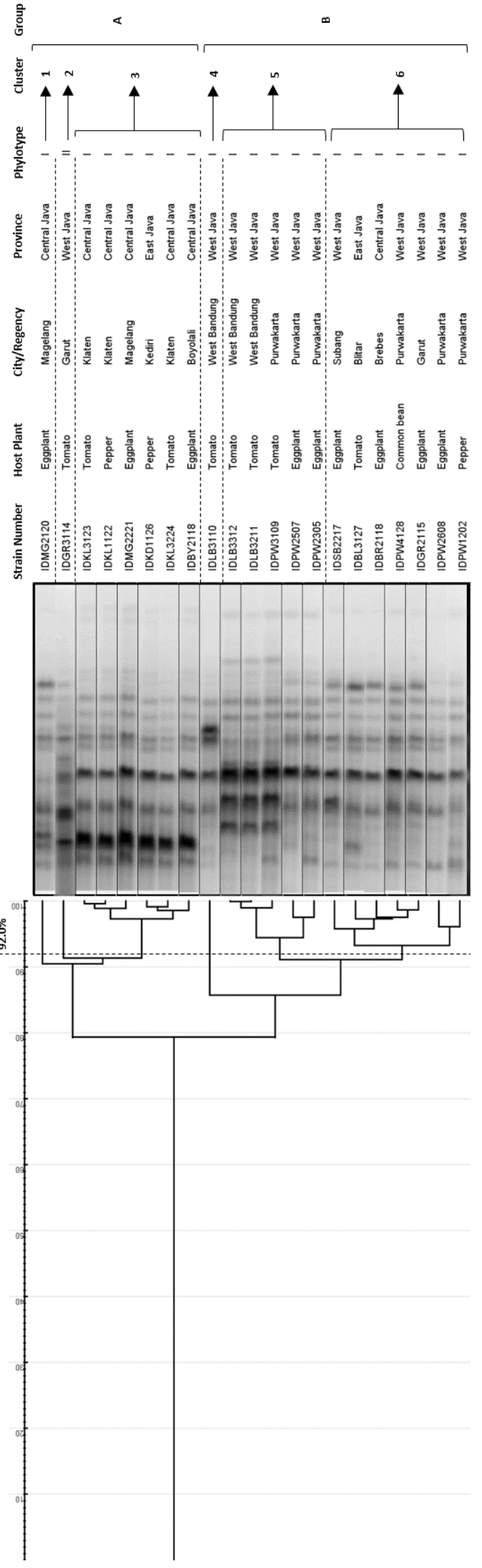

Figure 3. Analysis of BOX-PCR generated from 21 isolates of Ralstonia solanacearum. The dendrogram was generated using GelJ with a UPGMA algorithm applied to the similarity matrix generated by Pearson's correlation coefficient 


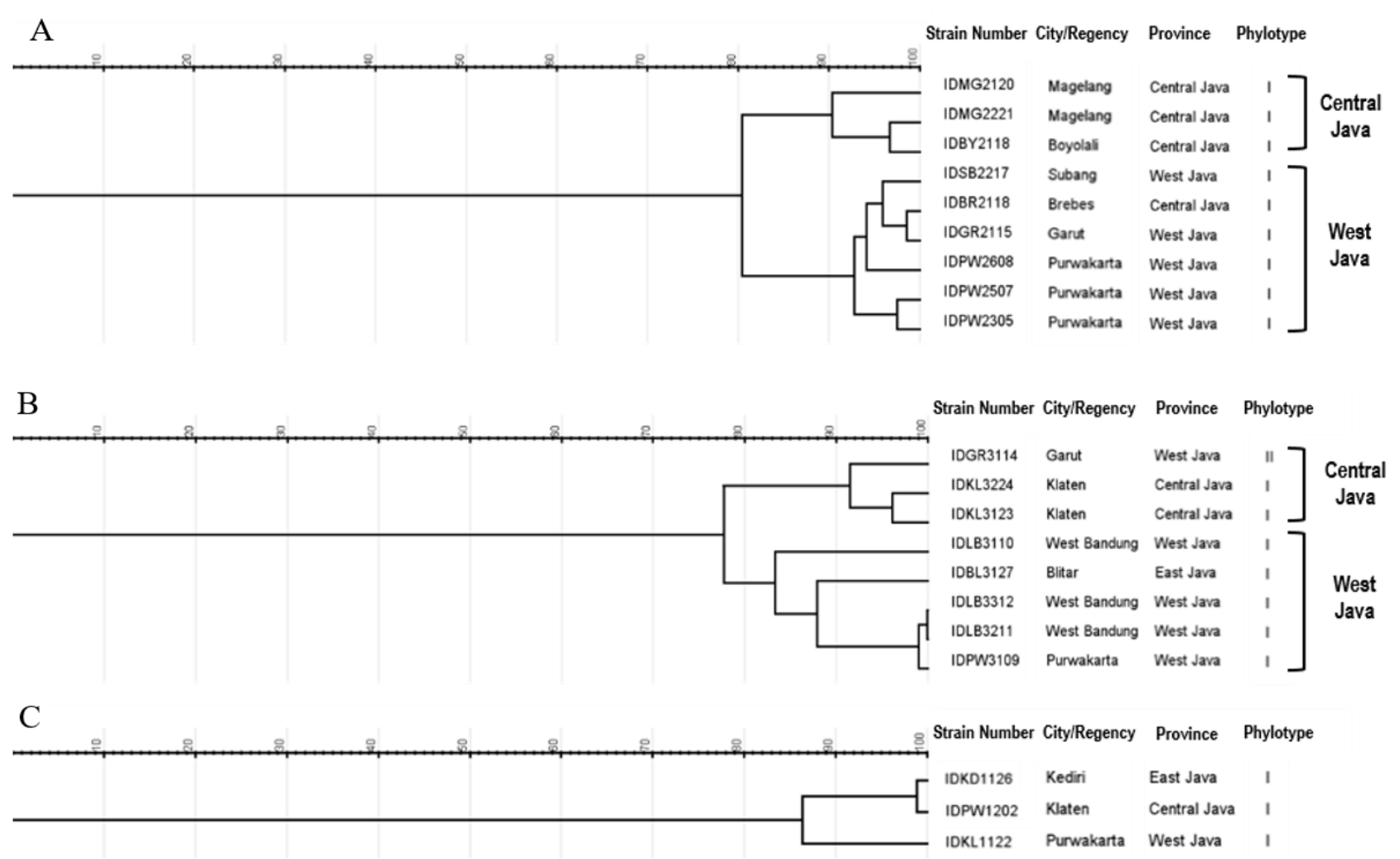

Figure 4. Analysis of BOX-PCR fingerprint based on host species, generated from Ralstonia solanacearum isolates from (A) eggplant, (B) tomato, and (C) pepper. The dendrogram was generated using GelJ with a UPGMA algorithm applied to the similarity matrix generated by Pearson's correlation coefficient

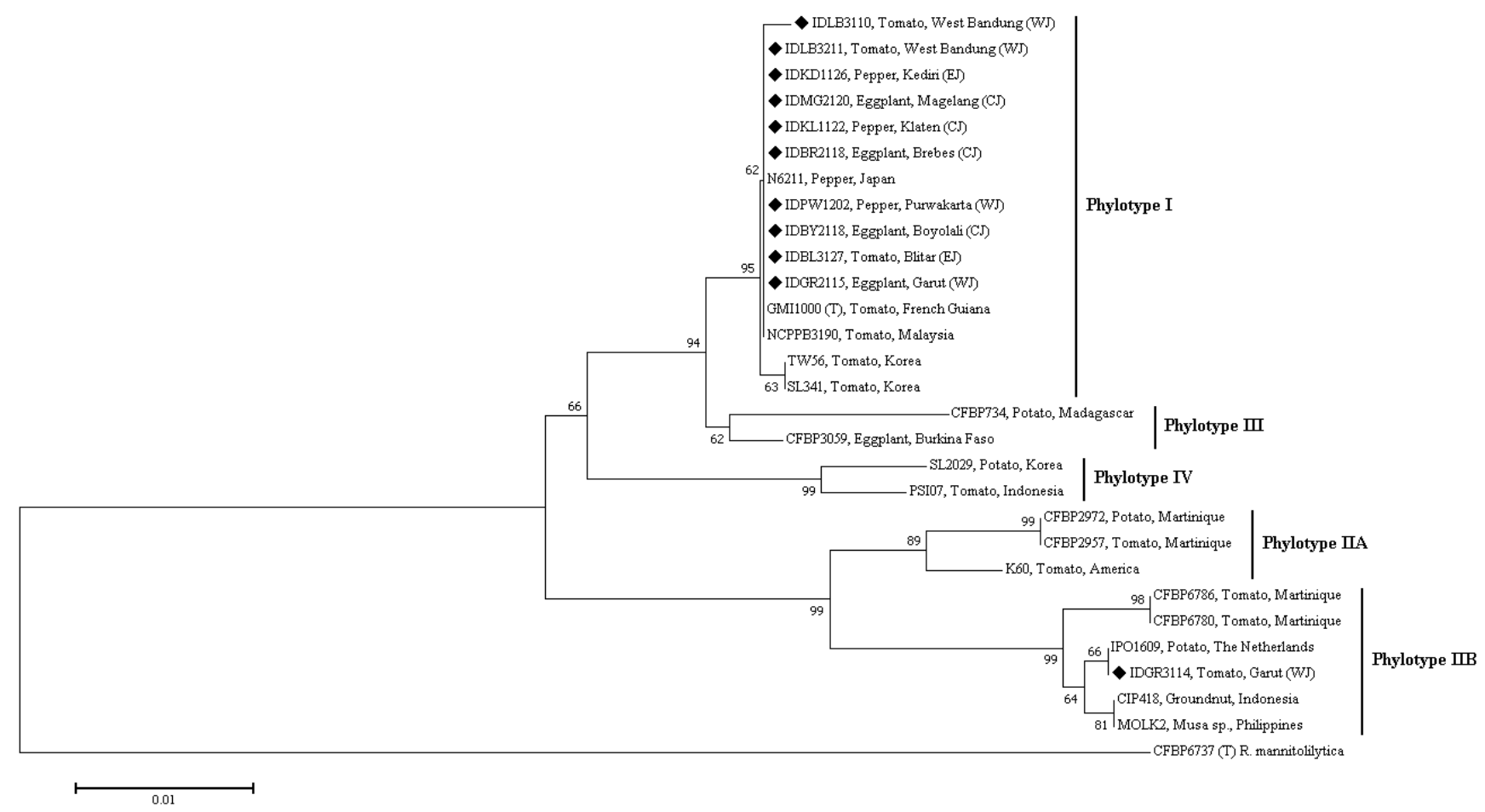

Figure 5. The phylogenetic tree of mutS gene generated by MEGA 7.0 using neighbor-joining algorithm and Jukes-Cantor as substitution model with 5000 times of bootstrap replication. The samples used in this study were marked by symbol. 
The IDGR3114 (Phylotype II R3bv2) isolate was identified as a phylotype IIB strain. This isolate was phylogenetically undistinguishable from the IPO1609 strain causing brown rot of potato in the Netherlands and spreading through contaminated potato seed tubers and irrigation water (Janse et al. 1998). Even though the R3bv2 strains present lower virulence and fitness at lowland tropical temperatures compared to the tropical strains of $R$. solanacearum such as GMI1000 (Huerta et al. 2015), these strains are adaptive to low temperature and show higher virulence at $20^{\circ} \mathrm{C}$ than the tropical strains (Milling et al. 2009). Moreover, the R3bv2 strains demonstrate the ability to remain detectable for four months in latently infected potato tubers at $4^{\circ} \mathrm{C}$ (Milling et al. 2009).

Phylotype II strains might be accidentally introduced to Indonesia by import-export activities of horticulture commodities, especially vegetative materials such as potato tubers or ginger rhizomes. It should be concerned that vegetative materials infected by $R$. solanacearum do not always show any symptoms of $R$. solanacearum infection. In latent infection, vegetative materials do not show any symptoms, but $R$. solanacearum remains intact on the parts of vegetative materials, such as on the surface, in lenticels, or even in the vascular tissue of (Hayward 1991).

In conclusion, this study reported that bacterial wilt disease in Java Island was caused by phylotype I strain which were able to infect a broad range of host plants, and a phylotype IIB R3bv2 strain which was adaptive to low temperature. Most of the phylotype I isolates were phylogenetically undistinguishable from each other as well as from the $R$. solanacearum type strain GMI1000 based on their mutS gene sequence. However, their genomic structures varied according to BOX-PCR analysis. Some of them showed genomic pattern based on their original site, but some of them did not. Further investigations will be needed to asses the pathogenicity and virulence of each strain because there might be different pathogenicity between strains, especially in phylotype I which has been known to be able to infect many host plant species. The fact that there are phylotype IIB R3bv2 strain outbreak in Indonesia, probably from long times ago, as well as the local contamination from one site to another will bring new challenges for the government, especially the Agency for Agricultural Quarantine of the Republic of Indonesia, and all seed companies in Indonesia to develop a sensitive diagnostic tool for detecting the latent infection of $R$. solanacearum as well as more effective bacterial wilt disease control strategies by considering the genetic background of $R$. solanacearum.

\section{ACKNOWLEDGEMENTS}

The authors would like to thank PT East West Seed Indonesia for funding our study as well as the staffs from the Laboratory of Plant Pathology PT East West Seed Indonesia for their assistance in collecting samples from infected plants and doing cross-testing. The authors also would like to thank the United States Agency for International Development (USAID) for training and mentoring support in writing this article, through the Sustainable Higher Education Research Alliance (SHERA) Program for Universitas Indonesia's Scientific Modeling, Application, Research, and Training for City-centered Innovation and Technology (SMART CITY) Project, and Jessica Kahler from University of Florida as our mentor for her willingness to give early review on this paper.

\section{REFERENCES}

Adriani, Rahman A, Gusnawati HS, Khaeruni A. 2012. Resistance response of tomato varieties to bacterial wilt disease. J Agroteknos 2: 63-68.

Arshiya M, Suryawanshi A, More D, Baig MMV. 2014. Repetitive PCR based detection of genetic diversity in Xanthomonas axonopodis pv citri strains. J Appl Biol Biotechnol 2: 17-22.

Carlos C, Alexandrino F, Stoppe NC, Sato MIZ, Ottoboni LMM. 2012. Use of Escherichia coli BOX-PCR fingerprints to identify sources of fecal contamination of water bodies in the State of Sao Paulo, Brazil. J Environ Manage 93: 38-43.

Coll NS, Epple P, Dangl JL. 2011. Programmed cell death in the plant immune system. Cell Death Differ 18: 1247-1256.

Dalsing BL, Truchon AN, Gonzalez-Orta ET, Milling AS, Allen C. 2015. Ralstonia solanacearum uses inorganic nitrogen metabolism for virulence, ATP production, and detoxification in the oxygen-limited host xylem environment. mBio 6: e02471-14.

Elphinstone JG. 2005. The current bacterial wilt situation: A global view. In: Allen C, Prior P, Hayward AC (eds) Bacterial Wilt Disease and the Ralstonia solanacearum Species Complex. American Phytopathological Society Press, Minnesota.

Fegan M, Prior P. 2005. How complex is the "Ralstonia solanacearum species complex"?, In: Allen C, Prior P, Hayward AC (eds) Bacterial Wilt Disease and the Ralstonia solanacearum Species Complex. American Phytopathological Society Press, Minnesota.

Hartati SY, Hadipoentyanti E, Amalia, Nursalam. 2015. Resistancescreening of patchouli somaclones on bacterial wilt disease (Ralstonia solanacearum). J Littri 21: 131-138.

Hayward, AC. 1964. Characteristics of Pseudomonas solanacearum. J Appl Bacteriol 27: 265-277.

Hayward, AC. 1991. Biology and epidemiology of bacterial wilt caused by Pseudomonas solanacearum. Annu Rev Phytopathol 29: 65-87.

Heras J, Domínguez C, Mata E, Pascual V, Lozano C, Torres C, Zarazaga M. 2015. GelJ - a tool for analyzing DNA fingerprint gel images. BMC Bioinformatics 16: 270-277.

Huerta AI, Milling A, Allen C. 2015. Tropical strains of Ralstonia solanacearum outcompete race 3 biovar 2 strains at lowland tropical temperatures. Appl Environ Microbiol 81: 3542-3551.

Ishii S, Sadowsky MJ. 2009. Applications of the rep-PCR DNA fingerprinting technique to study microbial diversity, ecology, and evolution. Environ Microbiol 11: 733-740.

Janse JD, Araluppan FAX, Wenneker SM, Westerhuis W. 1998. Experiences with bacterial brown rot Ralstonia solanacearum biovar 2, race 3 in the Netherlands, In: Prior P, Allen C, Elphinstone J (eds) Bacterial Wilt Disease: Molecular and Ecological Aspects. SpringerVerlag, Heidelberg.

Jeong Y, Cheong H, Choi O, Kim JK, Kang Y, Kim J, Lee S, Koh S, Moon JS, Hwang I. 2011. An HrpB-dependent but type IIIindependent extracellular aspartic protease is a virulence factor of Ralstonia solanacearum. Mol Plant Pathol 12: 373-380.

Koeuth T, Versalovic J, Lupski JR. 1995. Differential subsequence conservation of interspersed repetitive Streptococcus pneumonia BOX elements in diverse bacteria. Genome Res 5: 408-418.

Kumar S, Stecher G, Tamura K. 2016. MEGA7: Molecular evolutionary genetics analysis version 7.0 for bigger datasets. Mol Biol Evol 33: 1870-1874.

Larkin MA, Blackshields G, Brown NP, Chenna R, McGettigan PA, McWilliam H, Valentin F, Wallace IM, Wilm A, Lopez R, Thompson JD, Gibson TJ, Higgins DG. 2007. Clustal W and Clustal X version 2.0. Bioinformatics 23: 2947-2948.

Lemessa F, Zeller W, Negeri D. 2010. Genetic diversity among strains of Ralstonia solanacearum from Ethiopia assessed by repetitive 
sequence-based polymerase chain reaction (rep-PCR). Ethiopian Journal of Applied Sciences and Technology 1: 17-26.

Lozano JC, Sequeira L. 1969. Differentiation of races of Pseudomona solanacearum by a leaf infiltration technique. Phytopathology 60 833-838.

Lupski JR, Weinstock GM. 1992. Short, interspersed repetitive DNA sequences in prokaryotic genomes. J Bacteriol 174: 4525-4529.

Martiny JBH, Bohannan BJM, Brown JH, Colwell RK, Fuhrman JA, Green JL, Horner-Devine MC, Kane M, Krumins JA, Kuske CR, Morin PJ, Naeem S, Øvreås L, Reysenbach AL, Smith VH, Staley JT. 2006. Microbial biogeography: putting microorganisms on the map. Nat Rev Microbiol 4: 102-112.

Milling A, Meng F, Denny TP, Allen C. 2009. Interactions with hosts at cool temperatures, not cold tolerance, explain the unique epidemiology of Ralstonia solanacearum race 3 biovars 2 . Phytopathology 99: 1127-1134.

Muiru WM, Koopmann B, Tiedemann AV, Mutitu EW, Kimenju JW. Use of repetitive extragenic palindromic (REP), enterobacterial repetitive intergenic consensus (ERIC) and BOX sequences to fingerprint Exserohilum turcicum isolates. J Appl Biosci 30: 1828-1838.

Nasrun, Nurmansyah, 2016. The effectiveness of Pseudomonas fluorescens formulation to control bacterial wilt disease and to increase the growth of patchouli plant. J Fitopatol Indonesia 12: 4652.

Norman, DJ, Zapata M, Grabiel DW, Duan YP, Yuen JMF, MangravitaNovo A, Donahoo RS. 2009. Genetic diversity and host range variation of Ralstonia solanacearum strains entering North America. Phytopathology 99:1070-1077.

Olive DM, Bean P. 1999. Principles and application of methods for DNAbased typing of microbial organisms. J Clin Microbiol 37: 1661-1669.

Opina N, Tavner F, Hollway G, Wang JF, Li TH, Maghirang R, Fegan M, Hayward AC, Krishnapillai V, Hong WF, Holloway BW, Timmis JN. 1997. A novel method for development of species and strain-specific DNA probes and PCR primers for identifying Burkholderia solanacearum (formerly Pseudomonas solanacearum). Asia Pac J Mol Biol Biotechnol 5: 19-30.

Perez AS, Mejia L, Fegan M, Allen C. 2008. Diversity and distribution of Ralstonia solanacearum strain in Guatemala and the rare occurrence of tomato fruit infection. Plant Pathol 57: 320-331.

Phillip A, Janies D, Wheeler W. 2000. Multiple sequence alignment in phylogenetic analysis. Mol Phylogenet Evol 16: 317-330.

Prior P, Fegan M. 2005. Recent developments in the phylogeny and classification of Ralstonia solanacearum. Acta Hortic 695: 127-136.

Prior P, Ailloud F, Dalsing BL, Remenant B, Sanchez B, Allen C. 2016. Genomic and proteomic evidence supporting the division of the plant pathogen Ralstonia solanacearum into three species. BMC Genomics 17: 90 .

Proudy I, Bougle D, Coton E, Coton M, Leclercq R, Vergnaud M. 2008 Genotypic characterization of Enterobacter sakazakii isolates by PFGE, BOX-PCR and sequencing of the $f l i C$ gene. J Appl Microbiol 104: 26-34.

Safni I, Cleenwerck I, De Vos P, Fegan M, Sly L, Kappler U. 2014 Polyphasic taxonomic revision of the Ralstonia solanacearum species complex: proposal to amend the descriptions of Ralstonia solanacearum and Ralstonia syzygii and reclassify current $R$. syzygii strains as Ralstonia syzygii subsp. syzygii subsp. nov., $R$. solanacearum phylotype IV strains as Ralstonia syzygii subsp. indonesiensis subsp. nov., banana blood disease bacterium strains as Ralstonia syzygii subsp. celebesensis subsp. nov. and $R$. solanacearum phylotype I and III strains as Ralstonia pseudosolanacearum sp. nov. Int J Syst Evol Microbiol 64: 30873103.

Sagar V, Jeevalatha A, Mian S, Chakrabarti SK, Gurjar MS, Arora RK, Sharma S, Bakade RR, Singh BP. 2014. Potato bacterial wilt in India caused by strains of phylotype I, II, and IV of Ralstonia solanacearum. Eur J Plant Pathol 138: 51-65.

Salamah AR, Arwiyanto T. 2015. Sebaran Ralstonia solanacearum pada tomat berdasarkan keragaman genetik di wilayah Daerah Istimewa Yogyakarta dan provinsi Jawa Tengah. Abs Sem Nas Masy Biodiv Indon 2: 80.

Saputra R. Arwiyanto T, Wibowo A. 2015. Antagonistic activity and identification of some isolates of Bacillus spp. against bacterial wilt diseases (Ralstonia solanacearum) in some varieties of tomato. Pros Sem Nas Masy Biodiv Indon 1: 1116-1122.

Schell MA. 2000. Control of virulence and pathogenicity genes of Ralstonia solanacearum by an elaborate sensory network. Annu Rev Phytopathol 38: 263-292.

Suga Y, Horita M, Umekita M. Furuya N, Tsuchiya K. 2013. Pathogenic characters of Japanese potato strains of Ralstonia solanacearum. J Gen Plant Pathol 79: 110-114.

Vila J, Marcos MA, Jimenez de Anta MT. 1996. A comparative study of different PCR-based DNA fingerprinting techniques for typing of the Acinetobacter calcoaceticus-A. baumannii complex. J Med Microbiol 44: 482-489.

Wicker E, Grassart L, Coranson-Beaudu R, Mian D, Guilbaud C, Fegan M, Prior P. 2007. Ralstonia solanacearum strains from Martinique (French West Indies) exhibiting a new pathogenic potential. J Appl Environ Microbiol 73: 6790-6801

Wicker E, Lefeuvre P, de Cambiaire JC, Lemaire C, Poussier S, Prior P. 2012. Contrasting recombination patterns and demographic histories of the plant pathogen Ralstonia solanacearum inferred from MLSA. ISME J 6: 961-974.

Xu J, Pan ZC, Prior P, Xu JS, Zhang Z, Zhang H, Zhang LQ, He LY, Feng J. 2009. Genetic diversity of Ralstonia solanacearum strains from China. Eur J Plant Pathol 125: 641-653.

Xue Q, Yin Y, Yang W, Heuer H, Prior P, Guo J, Smalla K. 2011. Genetic diversity of Ralstonia solanacearum strain from China assessed by PCR-based fingerprints to unravel host plant and site dependent distribution. FEMS Microbiol Ecol 75: 507-519.

Yabuuchi E, Kosako Y, Yano I, Hotta H, Nishiuchi Y. 1995. Transfer of two Burkholderia and an Alcaligenes species to Ralstonia gen. nov.: Proposal of Ralstonia pickettii (Ralston, Palleroni and Doudoroff 1973) comb. nov. and Ralstonia eutropha (Davis 1969) comb. nov. Microbiol. Immunol 39: 897-904.

Yanti Y, Habazar T, Reflinaldon, Nasution CR, Felia S. 2017. Indigenous Bacillus spp. ability to growth promoting activities and control bacterial wilt disease (Ralstonia solanacearum). Biodiversitas 18: 1562-1567. 